\title{
IMPLEMENTASI VISI DESA BERDAYA KOTA BERJAYA \\ BERDASARKAN PERATURAN DAERAH KOTA BATU NOMOR 3 TAHUN 2018 TENTANG RPJMD TAHUN $2017-2022$
}

\author{
Saihul Anam \\ Kantor DPRD Kota Batu \\ Email : saikhulanam844@gmail.com
}

\begin{abstract}
Abstrak
Dengan ditetapkan Undang-Undang Nomor 11 Tahun 2001 Tentang Pembentukan Kota Batu tanggal 21 Juni 2001, terbentuklah Kota Batu sebagai daerah otonom baru di Jawa Timur. Sesuai dengan kewenangannya Pemerintah Daerah Kota Batu menetapkan Visi Desa Berdaya Kota Berjaya ke dalam RPJMD Tahun 20172022. Penelitan ini mengambil rumusan masalah: Produk hukum daerah apa sajakah yang sudah dan/atau belum dibentuk oleh Pemerintah Daerah Kota Batu sebagai daerah otonom, guna mengatur lebih lanjut UU Desa dan aturan pelaksanaannya untuk mewujudkan Visi Desa Berdaya Kota Berjaya? Bagaimanakah implementasi Visi Desa Berdaya Kota Barjaya, serta produk hukum daerah apa sajakah yang berpengaruh terhadap tercapainya Visi Desa Berdaya Kota Berjaya? Hal ini perlu dikemukakan karena pembahasan tentang Desa tidak lepas dari bingkai regulasi yang mengatur tentang Desa (UU Desa dan Peraturan-Peraturan pelaksanaannya). Penelitian ini menggunakan pendekatan yuridis empiris. Penelitian yang berbasis pada inventarisasi hukum positif, penemuan asas-asas hukum dan penemuan hukum inconcretto, yang dilengkapi pengamatan operasionalisasi asas-asas hukum secara empiris. implementasi Visi desa Berdaya Kota Berjaya memerlukan komitmen untuk pengaturan lebih lanjut baik secara atributif maupun delegatif sesuai regulasi tentang desa dengan peraturan daerah maupun peraturan walikota. Hal ini menjadi niscaya, karena desa dalam kontek UU Desa sudah bukan lagi sebagai obyek, malainkan ditempatkan sebagai subyek pembangunan. Saran yang bisa penulis sampaikan hendaknya pemerintah daerah melakukan revieu atas RPJMD 2017-2022, mendudukkan regulasi desa sebagaimana mestinya guna terwujudnya Desa Berdaya Kota Berjaya.
\end{abstract}

Kata kunci: Desa Berdaya, Visi, Desa Berdaya Kota Berjaya

\begin{abstract}
With the enactment of Law No. 11 of 2001 on the Establishment of Batu City on June 21, 2001, batu city was formed as a new autonomous region in East Java. This research takes the formulation of the problem: What regional legal products have been and/or have not been established by the Batu City Regional Government as an autonomous region, in order to further regulate the Village
\end{abstract}




\section{$\mathcal{H}$ urnal Negara dan $\mathcal{X}$ eadilan \\ p-ISSN 2302-7010 e-ISSN 2721-9801}

Law and its implementation rules to realize the Vision of The Empowered Village of BerjayaThe research uses an empirical juridical approach. The research is based on the inventory of positive laws, the discovery of legal principles and the discovery of inconcretto laws, which includes empirical observations of the operationalization of legal principles.

From the results of the research, the Vision of Empowered Village of Barjaya City, is realized by increasing the equalization of development in the village with idm indicator (Indek Desa Membangun). In conclusion, the implementation of The Vision of Berdaya Kota Berjaya village requires a commitment to further arrangements both attributely and delegatively in accordance with village regulations with local regulations and mayoral regulations.

Keywords: Shared property, polygamy, subdivision

\section{PENDAHULUAN}

Desentralisasi sebagai salah satu tuntutan gerakan Reformasi menajadi bagian yang tidak dapat dipisahkan dengan otonomi daerah. Dimana otonomi daerah adalah "hak, wewenang, dan kewajiban daerah otonom untuk mengatur dan mengurus sendiri Urusan Pemerintahan dan kepentingan masyarakat setempat dalam sistem Negara Kesatuan Republik Indonesia”. Sedangkan desentralisasi adalah "penyerahan Urusan Pemerintahan oleh Pemerintah Pusat kepada daerah otonom berdasarkan Asas Otonomi". Dan daerah otonom yang selanjutnya disebut Daerah adalah "kesatuan masyarakat hukum yang mempunyai batas-batas wilayah yang berwenang mengatur dan mengurus Urusan Pemerintahan dan kepentingan masyarakat setempat menurut prakarsa sendiri berdasarkan aspirasi masyarakat dalam sistem Negara Kesatuan Republik Indonesia”. ${ }^{1}$

Kota Batu lahir dan dibentuk dengan Undang- Undang Nomor 11 Tahun 2001 Tentang Pembentukan Kota Batu. Sebagai Daerah Otonom yang lahir pada Era Reformasi, maka Kota Batu menjadi bagian dari daerah otonom yang mencerminkan representasi pola politik hukum otonomi daerah, antara lain: melaksanakan sebagian urusan konkuren sebagai wujud desentralisasi, melaksanakan pengelolaan pemerintahan dengan egaliter dan demokratis (pelibatan masyarakat dalam penentuan dan pengambilan kebijakan daerah), serta pelaksanaan pemilihan kepala daerah secara langsung sebagaimana amanat undang-undang bidang pemilihan kepala daerah.

Dalam Peraturan Daerah Kota Batu Nomor 3 Tahun 2018 Tentang RPJMD Kota Batu Tahun 2018-2022, Kota Batu mengusung Visi "Desa Berdaya kota Berjaya". Visi "Desa Berdaya kota Berjaya" sebagai visi daerah sangat beralasan dan relevan mengingat Kota Batu wilayahnya mayoritas adalah Desa dan sebagian lagi adalah Kelurahan, dengan rincian Desa berjumlah 19 (Sembilan belas) dan kelurahan berjumlah 5 (lima).

1 Sinar Grafika, 2014, "Undang-Undang Nomor 23 Tahun 2014 TentangPemerintahan Daerah", Jakarta, Bab I, Pasal 1. 


\section{Jurnal Negara dan Keadilan \\ p-ISSN 2302-7010 e-ISSN 2721-9801}

Dalam kaitanya dengan pengaturan Desa, Negara telah menyediakan regulasi dalam bentuk Undang-Undang beserta peraturan pelaksanaannya. UndangUndang dimaksud adalah Undang-Undang Nomor 6 Tahun 2014 Tentang Desa (selanjutnya dibaca UU Desa). UU Desa maupun aturan pelaksanaannya, sebagian materinya baik secara atributif maupun delegatif memerlukan pengaturan lebih lanjut dalam dan/ atau dengan Peraturan Daerah maupun Peraturan Walikota.

\section{METODE PENELITIAN}

Metode pendekatan yang dipergunakan dalam penelitian ini adalah menggunakan metode pendekatan penelitian hukum empiris. Penelitian Hukum Empiris adalah suatu metode penelitian hukum yang menggunakan fakta-fakta empiris yang diambil dari perilaku manusia, baik perilaku verbal yang didapat dari wawancara maupun perilaku nyata yang dilakukan melalui pengamatan langsung. Penelitian empiris juga digunakan untuk mengamati hasil dari perilaku manusia yang berupa peninggalan fisik maupun arsip. ${ }^{2}$

\section{PEMBAHASAN}

1. Otonomi Daerah.

a. Pengertian Otonomi Daerah.

Bagir Manan dalam Agus Santoso mengemukakan bahwa otonomi adalah kebebasan dan kemandirian satuan pemerintahan lebih rendah untuk mengatur dan mengurus sebagian urusan pemerintahan. Urusan pemerintahan yang boleh diatur dan diurus secara bebas dan mandiri itu menjadi, atau merupakan urusan rumah tangga satuan pemerintahan yang lebih rendah tersebut. Kebebasan dan kemandirian merupakan hakikat isi otonomi. ${ }^{3}$

Hal ini selaras dengan pengertian otonomi daerah dalam UndangUndang Nomor 23 Tahun 2014 Tentang Pemerintahan Daerah, bahwa: "Otonomi Daerah adalah hak, wewenang, dan kewajiban daerah otonom untuk mengatur dan mengurus sendiri Urusan Pemerintahan dan kepentingan masyarakat setempat dalam sistem Negara Kesatuan Republik Indonesia". 4

b. Prinsip Otonomi Daerah.

Beberapa prinsip dalam pelaksanaan otonomi daerah sesuai dengan penjelasan atas Undang-Undang Nomor 23 Tahun 2014 Tentang Pemerintahan Daerah, dapat dirinci antara lain:

\footnotetext{
${ }^{2}$ Mukti Fajar dan Yulianto Achmad, 2010, "Dualisme Penelitian Hukum Empiris \& Normatif", Jakarta, Pustaka Pelajar, hlm.280.

${ }^{3}$ Ibid, hal. 31.

${ }^{4}$ Sinar Grafika, op.cit.
} 


\section{Zurnal Negara dan $\mathcal{X}$ eadilan \\ p-ISSN 2302-7010 e-ISSN 2721-9801}

1. Pemberian otonomi yang seluas-luasnya kepada Daerah.

2. Prinsip negara kesatuan.

3. Kebijakan yang dibuat dan dilaksanakan oleh Daerah merupakan bagian integral dari kebijakan nasional.

4. Keseimbangan antara kepentingan nasional. ${ }^{5}$

c. Tujuan Otonomi Daerah.

Sarundajang, ${ }^{6}$ menjelaskan tujuan otonomi daerah adalah sebagai berikut:

1. Dari segi politik adalah untuk mengikutsertakan, menyalurkan inspirasi dan aspirasi masyarakat, baik untuk kepentingan daerah sendiri, maupun untuk mendukung politik dan kebijaksanaan nasional dalam rangka pembangunan dalam proses demokrasi di lapisan bawah.

2. Dari segi manajemen pemerintahan, adalah untuk meningkatkan daya guna dan hasil guna penyelenggaraan pemerintahan, terutama dalam memberikan pelayanan terhadap masyarakat dengan memperluas jenis-jenis pelayanan dalam berbagai bidang kebutuhan masyarakat.

3. Dari segi kemasyarakatan, untuk meningkatkan partisipasi serta menumbuhkan kemandirian masyarakat, dengan melakukan usaha pemberdayaan (empowerment) masyarakat, sehingga masyarakat makin mandiri, dan tidak terlalu banyak tergantung pada pemberian pemerintah serta memiliki daya saing yang kuat dalam proses penumbuhannya.

4. Dari segi ekonomi pembangunan, adalah untuk melancarkan pelaksanaan program pembangunan guna tercapainya kesejahteraan rakyat yang makin meningkat.

2. Desentralisasi.

a. Pengertian Desentralisasi.

Sebagaimana dikemukakan Reynold Simandjutak, ${ }^{7}$ dalam "Sistem Desentralisasi Dalam Negara Kesatuan Republik Indonesia Perspektif Yuridis Konstitusional", mengutip beberapa pendapat, antara lain: Koesoemahatmadja bahwa "Desentralisasi merupakan suatu istilah yang secara etimologis merupakan bahasa Latin yang terdiri dari katade berarti lepas, dan centrum berarti pusat, sehingga bila diartikan, desentralisasi berarti melepaskan diri dari pusat".

Maksud pengertian tersebut bukan berarti daerah dapat berdiri sendiri melepaskan diri dari ikatan negara, tetapi dari sudut ketatanegaraan,

${ }^{5}$ Sinar Grafika, op. cit.

6 Sarundajang, 1999, "Arus Balik Kekuasaan Pusat ke Daerah", Jakarta, Pustaka Sinar Harapan, hlm. 36.

7 Reynold Simandjutak, 2015, "Sistem Desentralisasi Dalam Negara Kesatuan Republik Indonesia Perspektif Yuridis Konstitusional", Menado, Jurnal Syariah Dan Hukum, Universitas Negeri Menado, Vol. 7 No.1 Juni 2015. Hal. 59- 61. 


\section{$\mathcal{Z}$ urnal Negara dan $\mathcal{X}$ eadilan \\ p-ISSN 2302-7010 e-ISSN 2721-9801}

desentralisasi berarti pelimpahan kekuasaan pemerintahan dari pemerintah pusat kepada daerah-daerah untuk mengurus rumah tangganya sendiri. Dengan kata lain, daerah diberikan otonomi untuk menjadi daerah otonom.

Hal ini sejalan dengan penegertian desntralisasi sebagaimana dimaksud dalam Undang-Undang nomor 23 tahun 2014 Tentang Pemerintahan Daerah, bahwa : "Desentralisasi adalah penyerahan Urusan Pemerintahan oleh Pemerintah Pusat kepada daerah otonom berdasarkan Asas Otonomi". 8

b. Bentuk-Bentuk Desentralisasi.

Roy Marthen Moonti ${ }^{9}$ mengutip beberapa pendapat tentang beberapa bentuk desentralisasi, antara lain: Amrah Muslimin dalam Agus Santoso, membedakan tiga bentuk desentralisasi, yaitu desentralisasi politik, desentralisasi fungsional dan desentralisasi kebudayaan. Desentralisasi politik adalah pelimpahan kewenangan dari pemerintah pusat yang menimbulkan hak mengurus kepentingan rumah tangga sendiri bagi badan-badan politik di daerah-daerah yang dipilih oleh rakyat dalam daerah-daerah tertentu. Desentralisasi fungsional, adalah pemberian hak dan kewenangan padagolongan-golongan untuk mengurus macam kepentingan dalam masyarakat, baik terkait ataupun tidak pada suatu daerah tertentu seperti mengurus kepentingan irigasi bagi golongsan tani dalam suatu daerah. Desentralisasi kebudayaan, adalah memberikan hak pada golongangolongan kecil dalam masyarakat untuk menyelenggarakan kebudayaannya sendiri,seperti pendidikan, agama dan lain-lain.

c. Tujuan Desentralisasi.

Jika kita telaah dari berbagai Undang-Undang Pemerintahan Daerah sebagai dasar penyelenggaraan Otonomi Daerah, maka desentralisasi di Indonesia dapat dibedakan menjadi tiga Aspek :

a. Aspek Desentralisasi Finansial.

b. Aspek Desentralisasi Pemerintahan.

c. Aspek Desentralisasi Cultural.

Keberhasilan pelaksanaan desentralisasi dalam otonomi daerah dapat dilihat dari dua aspek, yaitu aspek output dan aspek outcomes kebijakan. Dimana masing-masing aspek memiliki ukuran atau indikator yang berbeda dalam menentukan penilaian keberhasilan. Muhammad Mujtaba Habibi, ${ }^{10}$ menjabarkan dua aspek tersebut dengan jelas, antara lain:

\footnotetext{
${ }^{8}$ Sinar Grafika, op. cit.

${ }^{9}$ Roy Marthen Moonti, op. cit. hal. 28.
}

10 Muhammad Mujtaba Habibi, 2015, "Analisis Pelaksanaan Desentralisasi Dalam Otonomi Daerah Kota/Kabupaten", Malang, Jurnal Pendidikan Pancasila dan Kewarganegaraan, Unuversitas Negeri malang, Th. 28, Nomor 2, Agustus 2015, hal. 118-119. 


\section{Zurnal Negara dan $\mathcal{X}$ eadilan \\ p-ISSN 2302-7010 e-ISSN 2721-9801}

1. Output Otonomi daerah dan desentralisasi.

Output kebijakan desentralisasi dapat dilihat dari beberapa aspek antara lain:

a. Pertumuhan ekonomi masyarakat.

b. Peningkatan kualitas pelayanan publik.

c. Fleksibilitas program pembangunan.

2. Outcomes Desentralisasi dalam Otonomi daerah.

Outcomes desentralisasi terdiri dari dua aspek, yaitu:

a. Peningkatan partisipasi masyarakat dan efektivitas pelaksanaan koordinasi.

b. Efektivitas pelaksanaan koordinasi, yaitu suatu proses pengintegrasian tujuan-tujuan dan kegiatan-kegiatan dari satuan yang terpisah (unit-unit atau bagian-bagian) suatu organisasi untuk mencapai tujuan organisasi secara efisien. Tanpa koordinasi individu-individu dan bagian-bagian akan kehilangan pandangan tentang peran mereka dalam organisasi.

3. Kewenangan Pemerintah Daerah Dalam Pemberdayaan Masyarakat Desa.

Dalam penyelenggaraan pemerintahan daerah dikenal beberapa urusan, salah satunya adalah urusan pemerintahan konkuren yaitu urusan pemerintahan yang dibagi antara Pemerintah Pusat dan Daerah provinsi dan Daerah kabupaten/kota. ${ }^{11}$ Urusan pemerintahan konkuren yang diserahkan ke Daerah menjadi dasar pelaksanaan Otonomi Daerah. ${ }^{12}$ Urusan pemerintahan konkuren yang menjadi kewenangan Daerah terdiri atas Urusan Pemerintahan Wajib dan Urusan Pemerintahan Pilihan. ${ }^{13}$ Urusan Pemerintahan Wajib terdiri atas Urusan Pemerintahan yang berkaitan dengan Pelayanan Dasar dan Urusan Pemerintahan yang tidak berkaitan dengan Pelayanan Dasar. ${ }^{14}$ Pemberdayaan masyarakat dan Desa termasuk dalam Urusan Pemerintahan yang tidak berkaitan dengan Pelayanan Dasar.

Desa mempunyai kewenangan sesuai dengan ketentuan peraturan perundang-undangan mengenai Desa. ${ }^{15}$ Sebagaimana uraian terdahulu bahwa kewenangan Desa berdasarkan Undang-Undang Desa meliputi kewenangan di bidang penyelenggaraan Pemerintahan Desa, pelaksanaan Pembangunan Desa, pembinaan kemasyarakatan Desa, dan pemberdayaan masyarakat Desa berdasarkan prakarsa masyarakat, hak asal usul, dan adat istiadat Desa. Kewenangan Desa tersebut meliputi:

1. Kewenangan berdasarkan hak asal usul;

${ }^{11}$ Undang-Undang Nomor 23 Tahun 2014 Tentang Pemerintah Daerah,Pasal 9 ayat (3).

${ }^{12}$ Undang-Undang Nomor 23 Tahun 2014 Tentang Pemerintah Daerah,Pasal 9 ayat (4).

${ }^{13}$ Undang-Undang Nomor 23 Tahun 2014 Tentang Pemerintah Daerah,Pasal 11 ayat (1).

${ }^{14}$ Undang-Undang Nomor 23 Tahun 2014 Tentang Pemerintah Daerah,Pasal 11 ayat (2).

15 Undang-Undang Nomor 23 Tahun 2014 Tentang Pemerintah Daerah, Pasal 371 ayat (2). 


\section{Jurnal Negara dan $\mathcal{X}$ eadilan \\ p-ISSN 2302-7010 e-ISSN 2721-9801}

2. Kewenangan lokal berskala Desa, yang meliputi:

a. kewenangan yang ditugaskan oleh Pemerintah, Pemerintah Daerah Provinsi, atau Pemerintah Daerah Kabupaten/Kota; dan

b. kewenangan lain yang ditugaskan oleh Pemerintah, Pemerintah Daerah Provinsi, atau Pemerintah Daerah Kabupaten/Kota sesuai dengan ketentuan peraturan perundang-undangan.

Sesuai dengan ketententuan Undang-Undang Desa ${ }^{16}$ dan peraturan perundang-undangan pelaksanaannya (Peraturan Pemerintah maupun Peraturan Menteri), pemerintah daerah berkewajiban membuat pedoman dalam bentuk produk hukum daerah, baik berupa Peraturan Daerah maupun Peraturan Kepala

\section{PENUTUP}

Produk hukum daerah yang sudah dibentuk dan yang belum dibentuk oleh Pemerintah Daerah Kota Batu sebagai daerah otonom, guna mengatur lebih lanjut UU Desa dan aturan pelaksanaannya untuk mewujudkan Visi Desa Berdaya Kota Berjaya.

1.1. Produk hukum yang sudah dibentuk.

a. Peraturan Daerah tentang Desa.

b. Peraturan Walikota Batu, yang antara lain:

1. Peraturan Walikota yang mengatur tentang pengelolaan keuangan desa.

2. Peraturan Walikota yang mengatur tentang pedoman penyusunan Anggaran Pendapatan dan Belanja Desa (APBDes).

3. Peraturan Walikota yang mengatur tentang pengadaan barang/jasa di desa.

4. Peraturan Walikota yang mengatur tentang Dana Desa (DD) yang bersumber dari APBN.

5. Peraturan Walikota yang mengatur tentang Alokasi Dana Desa (ADD) yang bersumber dari APBD.

6. Peraturan Walikota yang mengatur tentang bagi hasil pajak danretribusi daerah kepada desa.

7. Peraturan Walikota yang mengatur tentang asset desa.

8. Peraturan Walikota yang mengatur tentang kewenangan desa.

9. Peraturan Walikota yang mengatur tentang BUMDes.

10. Peraturan Walikota yang mengatur tentang Pemilihan KepalaDesa.

11. Peraturan Walikota yang mengatur tentang SOTK Desa.

12. Peraturan Walikota yang mengatur tentang penghasilankepala desa dan perangkat desa.

13. Peraturan Walikota yang mengatur tentang perangkat desa.

14. Peraturan Walikota yang mengatur tentang tunjangan BPD.

15. Peraturan Walikota yang mengatur tentang pemberian wewenang kepada Camat.

16 Undang-Undang Nomor 6 Tahun 2014 Tentang Desa, Pasal 115. 


\section{Jurnal Negara dan $\mathcal{X}$ eadilan \\ p-ISSN 2302-7010 e-ISSN 2721-9801}

1.2. Produk hukum daerah yang belum dibentuk.

1. Peraturan Walikota Tentang Tata Cara Penyusunan Peraturan di Desa. Merupakan amanat Peraturan Menteri Dalam Negeri Nomor 111 Tahun 2014 Tentang Pedoman Teknis Peraturan Di Desa, Pasal 32 ayat (2).

2. Peraturan Walikota Tentang Hasil Pengelolaan Tanah Bengkok Atau Sebutan Lain. Merupakan amanat Peraturan Pemerintah Nomor 47 Tahun 2015 tentang Perubahan Peraturan Pemerintah Nomor 43 Tahun2014 Tentang Peraturan Pelaksanaan Undang- Undang Nomor 6 Tahun 2014 Tentang Desa, Pasal 103 ayat (4).

3. Peraturan Walikota Tentang Petunjuk Teknis Penyusunan RPJM Desa, RKP Desa dan Petunjuk Teknis Pelaksanaan Kegiatan Pembangunan Desa. Merupakan amanat Peraturan Menteri Dalam Negeri Nomor 114 Tahun 2014 Tentang Pedoman Pembangunan Desa, Pasal 89, dan Permendes PDTT Nomor 17 tahun 2019 PEDOMAN UMUM PEMBANGUNAN DAN PEMBERDAYAAN MASYARAKAT DESA, Pasal 7 ayat (6).

4. Peraturan Walikota Tentang Peta Batas Desa. Merupakan amanat Peraturan Menteri Dalam Negeri Nomor 45 Tahun 2016 Tentang Pedoman Penetapan dan Penegasan batas Desa, Pasal 8 ayat (1).

5. Peraturan Wali Kota Tentang Tata Naskah Dinas Untuk Desa.

Merupakan amanat Peraturan Menteri Dalam Negeri Nomor 2 Tahun 2017 Tentang Standar Pelayanan Minimal Desa, Pasal 10 ayat (2).

6. Peraturan Wali Kota Tentang SPM Desa. Merupakan amanat Peraturan Menteri Dalam Negeri Nomor 2 Tahun 2017 Tentang Standar Pelayanan Minimal Desa, Pasal 12 ayat (2).

2. Implementasi Visi Desa Berdaya Kota Berjaya.

2.1. Implementasi Visi Desa Berdaya Koya Berjaya dengan mewujudkan keberdayaan desa oleh Pemerintah Daerah Kota Batu dimasukkan pada arah kebijakan pembangunan tahun 2022.

2.2. Guna mewujudkan keberdayaan desa telah ditetapkan 3 (tiga) sasaran, antara lain:

a. Sasaran 1 (S1), adalah Meningkatnya penataan ruang dan infrastruktur kota yang terpadu, berkelanjutan dan berketahananbencana;

b. Sasaran 2 (S2), adalah Meningkatnya Kualitas Pembangunan Desa;

c. Sasaran 3 (S3), adalah meningkatnya Kualitas Lingkungan HidupDesa.

2.3. Guna mewujudkan keberdayaan desa, pemerintah daerah seharusnya memasukkan pengaturan lebih lanjut UU Desa dengan produk hukum daerah ke dalam strategi yang dimuat pada 


\section{Zurnal Negara dan $\mathcal{X}$ eadilan \\ p-ISSN 2302-7010 e-ISSN 2721-9801}

RPJMD, karena bahwa pembahasan tentang desa dari berbagai sisi, harus pula mendasarkan pada UU Desa.

2.4. Produk hukum daerah yang berkaitan dengan desa yang juga berpengaruh atas terwujudnya visi desa berdaya kota barjaya antara lain:

a. Jenis Peraturan daerah.

- Peraturan Daerah Kota Batu yang mengatur tentang Desa (Peraturan Daerah Kota Batu Nomor 1 Tahun 2015 Tentang Desa, sebagaimana telah diubah dengan Peraturan Daerah Kota Batu Nomor 5 Tahun 2018 Tentang Perubahan Atas Peraturan Daerah Kota Batu Nomor 1 Tahun 2015 Tentang Desa).

b. Jenis Peraturan Walikota.

1. Peraturan Walikota yang mengatur tentang besaran Alokasi Dana Desa, Dana Desa dan Bagi hasil pajak dan retribusi daerah kepada desa.

2. Peraturan Walikota yang mengatur tentang pengelolaan keuangan desa.

3. Peraturan Walikota yang mengatur tentang pedoman penyusunan Anggaran Pendapatan Dan Belanja Desa (APBDes).

4. Peraturan Walikota yang mengatur tentang pengelolaan asset desa;

5. Peraturan Walikota yang mengatur tentang pengadaan barang/ jasa di desa;

6. Peraturan Walikota yang mengatur tentang daftar kewenangan desa berdasarkan hak asal usul dan kewenangan bersekala local desa.

7. Peraturan Walikota Tentang Tata Cara Penyusunan Peraturan di Desa.

8. Peraturan Walikota Tentang Hasil Pengelolaan Tanah Bengkok Atau Sebutan Lain.

9. Peraturan Walikota Tentang Petunjuk Teknis Penyusunan RPJM Desa, RKP Desa dan Petunjuk Teknis Pelaksanaan Kegiatan Pembangunan Desa.

10. Peraturan Wali Kota Tentang SPM Desa.

\section{Buku}

\section{DAFTAR PUSTAKA}

Fajar, Mukti dan Yulianto Achmad, 2010, "Dualisme Penelitian Hukum Empiris \& Normatif”, Jakarta: Pustaka Pelajar.

Sarundajang, 1999, “Arus Balik Kekuasaan Pusat ke Daerah”, Jakarta: Pustaka Sinar Harapan.

Setiawan, Irfan, 2018, "Handbook Pemerintahan Daerah", Yogyakarta: Penerbit Wahana Resolusi. 


\section{Hurnal Negara dan $\mathcal{X}$ eadilan \\ p-ISSN 2302-7010 e-ISSN 2721-9801}

Soekanto, Soerjono, at all, 1985, "Penelitian Hukum Normative Suatu Tinjauan Singkat”, Jakarta: Raja Grafindo Persada.

Soekanto, Soerjono, 2014, "Pengantar Penelitian Hukum”, Jakarta: Universitas Indonesia.

Sydzily, TB. H. Ace Hasan, 2019, “Desentralisasi, Otonomi, Dan Pemekaran Daerah Di Indonesia”, Jakarta: Prenada Media Group.

Jurnal Ilmiah/Hasil Penelitian

Bapelitbangda, 2018, "Rencanan Pembangunan Jangka Menengah Daerah Kota Batu Tahun 2018-2022”, Batu.

Habibi, Muhammad Mujtaba, 2015, "Analisis Pelaksanaan Desentralisasi Dalam Otonomi Daerah Kota/Kabupaten”, Malang: Jurnal Pendidikan Pancasila dan Kewarganegaraan, Universitas Negeri Malang, Th. 28, Nomor 2, Agustus 2015.

Hayati, Tri, 2005, "Pilkada Dalam Era reformasi Pemerintahan Daerah (Pasca Putusan MK)", Jakarta, Jurnal konstitusi, vol. 2, no. 1 Juli 2005.

Hisyam, Djihad, 2004, "Desentralisasi, Otonomi Daerah, Dan Pembangunan", Yogyakarta: Majalah Ilmiah WUNY-UNY, Vol IV No 1 Februari 2004.

Kholis, Nur, 2013, "Pengaruh Politik Dalam Perkembangan Praktek Ekonomi Islam Di Indonesia”, Yogyakarta: Millah Jurnal Studi Agama. Vol. XIII.

Moonti, Roy Marthen, 2017, "Hakikat Otonomi Daerah Dalam Sistem Ketatanegaraan Di Indonesia”, Jurnal Balireso, Vol. 19 No. 2 November 2017.

Nugraha, Al Fajar dan Atika Mulyandari, 2016, "Pilkada Langsung Dan Pilkada Tidak Langsung Dalam Perspektif Fikih Siyasah", Samarinda, Jurnal Pemikiran Hukum Islam "Mazahib”, Vol. XV, No. 2 Desember 2016.

Nuradhawati, Rira, 2019, "Dinamika Sentralisasi Dan Desntralisasi Di Indonesia”, Jakarta: Jurnal Academia Praja Universitas Jenderal Ahmad yani, Volume 2 No 1 - Februari 2019.

Simandjutak, Reynold, 2015, "Sistem Desentralisasi Dalam Negara Kesatuan Republik Indonesia Perspektif Yuridis Konstitusional”, Manado: Jurnal Syariah Dan Hukum, Universitas Negeri Menado, Vol. 7 No.1 Juni 2015.

Soemardi, Dedi, 1988, "Masalah Desentralisasi”, Depok: Jurnal Hukum Dan Pembangunan.

Sugiman, 2018, "Pemerintahan Desa”, Jakarta, Jurnal Binamulia Hukum Vol. 7 No. 1, Juli 2018.

Oktaviani, Jusmalia dan Teguh Puja Pramadya, 2019, "Model Negara

Kekuasaan: Orde Baru dalam Tinjauan Pemikiran Hobbes dan Niccolo

Machiavelli,, Semarang: Jurnal Indonesian Perspective.

Sinar Grafika, 2014, "Undang-Undang Nomor 23 Tahun 2014 Tentang Pemerintahan Daerah”, Jakarta.

\section{Peraturan Perundang-Undangan}

Undang-Undang Nomor 25 Tahun 2004 Tentang Sistem Perencanaan Pembangunan Nasional.

Undang-Undang Nomor 6 Tahun 2014 Tentang Desa.

Undang-Undang Nomor 23 Tahun 2014 Tentang Pemerintahan Daerah. 